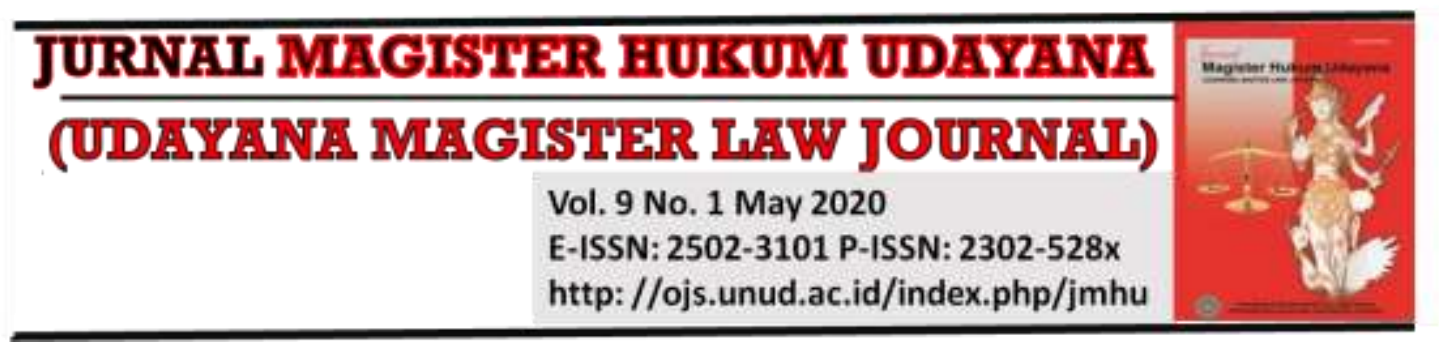

\title{
Vagrants and Beggars Countermeasures at Denpasar City in Criminology Perspective
}

\section{Gde Made Swardhana ${ }^{1}$}

${ }^{1}$ Faculty of Law Udayana University, E-mail: gdmade_swardhana@unud.ac.id

\begin{tabular}{l}
\hline Info Article \\
\hline Received: $9^{\text {th }}$ Maret 2020 \\
Accepted: $30^{\text {th }}$ Mei 2020 \\
Published: $31^{\text {st }}$ Mei 2020 \\
Keywords: \\
Vagrants; Beggars; \\
Countermeasures. \\
Corresponding Author: \\
Gde Made Swardhana, Email: \\
gmswar@yahoo.com \\
DOI: \\
10.24843/JMHU.2020.v09.i01. \\
p02
\end{tabular}

\begin{abstract}
The purpose of this research article is to find out and analyze criminological problems with vagrants and begging. The problem of vagrants and beggars in Denpasar is very complex, related to legal, social, economic, mental, and cultural aspects of the community. Vagrants and begging are regulated in Articles 504 and 505 Criminal Act, also the Regional Regulation of the City of Denpasar No. 15 of 1993 jo. No. 3 of 2000 concerning Cleanliness and Public Order. This research is empirical law with document study and interview techniques. Analysis of legal materials using descriptive, argumentative, and evaluative. The result is found that the causes of vagrant and beggars are internal factors, namely poor living; age; Education; and mental attitude. External factors, namely: the condition of water demand; crop conditions for agriculture, and limited access to information and business capital. Related to the effort to overcome vagrant people and beggars include preventive, repressive, and rehabilitative efforts.
\end{abstract}

\section{Introduction}

Vagrants and beggars are one of the problems hampering the progress of the country, vagrants and beggars are a negative impact of development, especially urban development. The majority of vagrant and beggars come from families who are poor and economically disadvantaged ${ }^{1}$. Urban is the center of economy, culture, politics and government so that many people who come to the city and even settled ${ }^{2}$. The successful acceleration of development in urban areas and vice versa delayed development in rural areas invites the flow of migration or urbanization from villages

\footnotetext{
${ }^{1}$ Bahfiarti, T., Muhammad, R., \& Tarawe, A. (2019). Kajian Penanganan Anak Gelandangan Dan Pengemis Di Kota Makassar (Study on Handling of Children and Beggars in Makassar City). Jurnal Inovasi dan Pelayanan Publik Makassar, 1(2), 43-54.

2 Zefianningsih, B. D., Wibhawa, B., \& Rachim, H. A. (2016). Penanggulangan Gelandangan Dan Pengemis Oleh Panti Sosial Bina Karya "Pangudi Luhur" Bekasi. Prosiding Penelitian dan Pengabdian kepada Masyarakat, 3(1). 1-18.
} 
to cities which, among others, can cause vagrant and beggars because of the difficulty in finding housing and employment in urban areas ${ }^{3}$.

Currently a big city in Indonesia, the distribution and the number of vagrant and beggars are quite high. Based on the data of 40 people in the category of street children and beggars there were $18(16.7 \%)$ women and $30(83.3 \%)$ men who were male. This data illustrates that street children are more male than females with a ratio of $83.3 \%$ and $16.7 \%$. Boys dominate more than girls. In the interaction between street children and beggars, they interact and coordinate with each other in their actions and actions in attracting the sympathy of the community to voluntarily give them money. One of them is in Denpasar City, wherein some corners of the city and the center of the crowd it is very easy to find these vagrants and beggars. The problem here is that their existence is endless, even at certain times the numbers are increasing, such as on the eve of religious holidays and the holiday season. The existence of the invasion of beggars and beggars is indeed difficult to dammed and obviously also has made busy the Denpasar City Government to deal with it ${ }^{4}$.

Impacts caused by vagrant people and beggars include the emergence of social rules ${ }^{5}$. This condition is very alarming and unsettling the people of Denpasar City as a metropolitan city considering that the existence of vagrants people and beggars besides being a social disease also contradicts the values of the Pancasila and the personality of the Indonesian nation, it has been radically assessed as a social behavior that deviates from the normative culture 6 . Vagrants and beggars also have the potential to increase crime rates and cause disruption to security and public order such as extortion, theft and child trafficking syndicates. The problem of vagrant people and beggars can certainly cause a bad image or a negative impression on the city of Denpasar itself as the capital, economic center and central government of the Province of Bali whose social development always gets the attention of the wider community and is also a distortion of world tourism.

The problem of vagrants and beggars is a very complex problem and is not without reason, their existence in addition to intersecting with legal aspects is also closely related to social aspects such as economic, mental and cultural society and religion? Development of Street Children Based on Regional Regulation No. 2 of 2008 In Makassar City, the Faculty of Social Sciences Makassar State University found that the form of street child development carried out by the Makassar City Social Service as the implementation of Regional Regulation No. 2 of 2008, included social rehabilitation; empowerment, continued guidance and community participation. Based on data from

\footnotetext{
${ }^{3}$ Direktorat Jenderal Rehabilitasi Sosial Kementerian Sosial RI. (2010), Fenomena Munculnya Gelandangan dan Pengemis. http://rehsos.kemsos.go.id/modules.php/article=1066. accessed Desember 3, 2013.

${ }^{4}$ Anonymous. (2013). Tak Mempan Dirazia, Gepeng Muncul di Kuta. Jawa Pos Radar Bali. date June 21, 2013, page 23, column 5.

${ }^{5}$ Dahri, I. (2016). Studi Tentang Perlindungan Dan Pembinaan Gelandangan Anak Di Kota Makassar. Jurnal Tomalebbi, (2), 1-12.

${ }^{6}$ Nusanto, B. (2017). Program Penanganan Gelandangan Dan Pengemis Di Kabupaten Jember (Handling Programs Of Vagrants And Beggar) In Jember District. Politico, 17(2). 339-360

7 Rohmaniyati, R. (2016). Pemberdayaan Gelandangan Dan Pengemis (Gepeng) Melalui Usaha Ekonomi Produktif (UEP) Di Lembaga Sosial Hafara Bantul, Daerah Istimewa Yogyakarta. Jurnal Elektronik Mahasiswa Pend. Luar Sekolah-S1, 5(2).
} 
the Social Service (2019), 504 street children, beggars and street singers who were netted during 2018 (street children, vagrants people, buskers, glue drugs), while from January to August 2019, 264 people were netted by PMKS patrols. Based on these symptoms and phenomena, the focus of treatment on street children, beggars, vagrant people and other types that have the potential to cause a sense of insecurity and comfort for the community. Forms of coaching and empowerment become an alternative solution to foster the concern of the Makassar City Government on humanitarian issues and social aspects.

The Government of Denpasar City together with the relevant law enforcement agencies have indeed carried out relief measures and continually improved to overcome tackling vagrantsness and beggars in Denpasar City if previously had installed billboards containing appeals so as not to give alms to vagrant and beggars, then leaflets visited appeal to be invited not to give something to the vagrants and beggars ${ }^{8}$. Vagrants and beggars' countermeasures will be able to realize national challenges, specifically in the field of defense and security is needed for a studio that is able to improve as a whole? .

This study aims to examine and analyze the factors that cause vagrant and beggars and efforts to overcome them in the city of Denpasar by analysis the theory of Walter C Reckless about Containment theory In addition to reviewing and analyzing prevention efforts in criminological perspectives on vagrants and beggars who occurred in Denpasar City with the analysis of causal factors and prevention efforts namely Preventive, and Repressive as stated by Edward H. Sutherland and Cressey as well as the study of countermeasures by Graham with primary, secondary and tertiary prevention models.

The context of this research is in a criminological perspective so that countermeasures carried out can emphasize the efforts of mediating penalties without being ensnared by the provisions of criminal law but it is hoped that in the future vagrant people and beggars will no longer decorate the streets of Denpasar.

\section{Research Method}

The research method used in this study is the empirical legal research method. In legal science research with empirical aspects, the law is conceptualized as an empirical phenomenon that can be observed in real life. Secondary data in this study is used as initial data and then continued with primary data or field data. Empirical legal research still refers to the normative premise where the operational definition can be taken from the legislation to Act No. 11 of 2009 concerning Social Welfare; Government Regulation No. 39 of 2012 concerning Implementation of Social Welfare; Government Regulation No. 31 of 1980 concerning the Management of Bums and Beggars; Criminal act; Regional Regulation of Denpasar City No. 15 of 1993 jo. No. 3 of 2000 concerning Cleanliness and Public Order. Next look at the implementation of reality in the field

\footnotetext{
8 Anonymous. (2012). Siaga Gepeng Himbauan. http://koranbalitribune.com/2012/04/15/siaga-gepeng-sebar-imbauan/. accessed September 3, 2013.

9 Iqbali, S. (2006). Studi Kasus Gelandangan-Pengemis (Gepeng) Di Kecamatan Kubu Kabupaten Karangasem. Piramida, 4(1).
} 
(Das Solen and Das Sein). Data collection techniques used document study techniques to collect secondary data and in-depth interview techniques to collect primary data with the Head of the Office of Social Affairs and Labour of the City of Denpasar, as well as several vagrant and beggars raided by officers around the city of Denpasar. In this case the technique of determining the research sample used is non-probability sampling meaning that in this study there are no definite provisions on how many samples should be taken to represent the population. Techniques in analyzing legal materials used in the analysis of this study are descriptive, argumentative and evaluative.

\section{Results and Discussion}

The problem of vagrant people and beggars in Denpasar City can be seen from the data and information obtained at the Social and Labour Office of the City of Denpasar, it turns out that in the 2012 period alone the number of vagrant people and beggars who were disciplined or captured/netted raids was 304 people, the details are 15 vagrants people and 289 beggars. From this number, it is known that most of the vagrant and beggars turned out to be from Karangasem and others from several areas in Bali and outside Bali ${ }^{10}$. This fact shows that the number of vagrants and beggars scattered in the Denpasar City area is still high.

Compared to other areas in Bali, such as the Regency of Buleleng, the number of vagrant and beggars in Denpasar City is much higher. The researcher chose Buleleng Regency as a comparison material in this study considering the population and area of Buleleng Regency are the largest in Bali Province and current developing in the region is developing quite rapidly. According to data owned by the Social Service Office of Buleleng Regency, in the same period of the year 2012, the number of vagrant people and beggars who were disciplined or captured/netted by raids by relevant authorities or agencies in Buleleng Regency were only 75 people, 10 of them were vagrants and 65 beggar people ${ }^{11}$.

We cannot deny the problem of vagrant people and beggars is a very complex problem because in addition to dealing with legal aspects it is also closely related to social aspects such as economic, mental and cultural community so that it is natural that here requires more comprehensive prevention or handling from the authorities law enforcement and Denpasar City Government by involving all elements of society.

It needs to be stated to get the same understanding of what vagrant sand Beggars are and the provisions governing Vagrants and Beggars.

\section{Understanding of Vagrants and Beggars}

The word vagrants and beggars are often abbreviated as "vagrants". The Indonesian people are generally familiar with the acronym/abbreviation "vagrants" (vagrant and beggar) which is not only a common vocabulary in everyday conversation and the topic of mass media coverage, but also has become a term in government policy referring to a group of people who are commonly found in big cities.

10 Data at the Office of Social Affairs and Labor City of Denpasar. (2014). The study was conducted in December 2014 to March 2015.

${ }^{11}$ Data at Buleleng Regency Social Service. (2013). The study was conducted on August 12, 2013. 
Another vocabulary which is also often used to mention the existence of vagrants and beggars in the Indonesian people are vagrants. ${ }^{12}$ If we look and compare with the phenomena of vagrants and beggars that occur abroad like the United States, then the popular term used in the United States to mention vagrants and beggars is vagrants.

According to the provisions of Government Regulation Republic of Indonesia No. 31 of 1980 on the Prevention of Vagrants and Beggars referred to by vagrants and beggars are:

- Vagrants are people who live in a state not in accordance with the norms of decent living in the local community, and do not have permanent residence and work in certain areas and live to wander in public places;

- Beggars are people who earn income by asking in public in various ways and reasons to expect compassion from others.

The Ministry of Social Affairs of the Republic of Indonesia also provides the same formulation with the Government Regulation of the Republic of Indonesia no. 31 of 1980 on the Prevention of Vagrants and Beggars on the meaning of vagrants and beggars are:

Vagrants are people who live in a state incompatible with decent living norms in the local community and have no permanent residence and work in a particular area and live in public places. Beggars are people who earn income from begging in public for various reasons to expect compassion from people. ${ }^{13}$

Furthermore, the Big Indonesian Dictionary mentioned that the definition of a vagrant is "people who do not have a fixed residence, not necessarily work, wandering, pacing here and there is not necessarily the purpose, adventure". Next, the notion of a beggar is "the people who are begging". ${ }^{14}$

According to Parsudi Suparlan, vagrants mean always moving, not fixed and sedentary. He also expressed his opinion on what is meant by the vagrants' community is the number of people who together have relatively irregular shelter and relatively non-permanent livelihoods and are considered low and lowly by the people outside the small community which is a wider society. The actions taken by its members and the norms of the vagrants are deemed inappropriate and not justified by other groups in the wider society that includes the small community.

Furthermore, specifically for the word beggar is commonly used for the designation for people who need money, food, shelter, or other things from people they meet by asking. Various attributes they use, such as tattered and shabby clothes, hats, plastic cups or candy wrappers, or small boxes to put the money they get from begging. They

12 Ahmad, M. (2010). Strategi Kelangsungan Hidup Gelandangan-Pengemis (Gepeng). Jurnal Penelitian, 7(2), 1-16.

${ }^{13}$ Direktorat Pelayanan dan Rehabilitasi Sosial Tuna Sosial. (2005). Standar Pelayanan Minimal Pelayanan dan Rehabilitasi Sosial Gelandangan dan Pengemis. Jakarta: Depsos RI.

${ }^{14}$ Ibid, h. 532. 
make begging for their work for a variety of reasons, such as poverty and their helplessness due to the narrow field of work. ${ }^{15}$

\section{Legislation Related Prevention of Vagrants and Beggars}

Efforts to overcome or handling the problem of vagrants and beggars in Indonesia, especially those occurring also in Denpasar, there are some relevant legal rules and can be used as guidelines/foundation are:

1. Law of the Republic of Indonesia No. 11 of 2009 concerning Social Welfare (State Gazette of the Republic of Indonesia of 2009 No. 12, Supplement to the State Gazette of the Republic of Indonesia No. 4967);

2. Government Regulation of the Republic of Indonesia No. 39 of 2012 on the Implementation of Social Welfare (State Gazette of the Republic of Indonesia of 2012 No. 68, Supplement to the State Gazette of the Republic of Indonesia No. 5294);

3. Government Regulation of the Republic of Indonesia no. 31 of 1980 on the Prevention of Vagrants and Beggars (State Gazette of the Republic of Indonesia Year 1980 No. 51, Supplement to State Gazette of the Republic of Indonesia No. 3177);

4. Criminal Code (KUHP);

5. Local Regulation of Denpasar City no. 15 of 1993 jo. No. 3 of 2000 on Public Cleanliness and Public Order (Lembaran Daerah Kota II, Denpasar No. 1 of 1994 D Series No. 1, Denpasar District Gazette No. 4 of 2000).

The above description can be explained as follows:

1. Act of the Republic of Indonesia No. 11 Year 2009 on Social Welfare

According to the Law of the Republic of Indonesia No. 11 Year 2009 on Social Welfare vagrants and beggars are categorized as groups of people who experience social dysfunction or Social Welfare Problems. As a rule of law on social welfare in Indonesia, this Law emphasizes the main activities of social welfare for the society which is prioritized to those who have a life that is not humanly deserving and has criteria of social problems: poverty, neglect, disability, remoteness, social offspring and deviations of perpetrators, victims of disaster, and or victims of violence, exploitation and discrimination (Articles 2 and 5 of Law of the Republic of Indonesia No. 11 Year 2009). Within this scope vagrants and beggars are clearly a community group experiencing poverty problems so that the social welfare activities must touch vagrants and beggars.

The provisions of Article 6 of Law RI No. 11 Year 2009 affirmed that the implementation of social welfare covers:

${ }^{15}$ Dimas Dwi Irawan, 2013, Beggar Undercover Secrets About Beggar's Life, Titik Media Publisher, Jakarta, h. 1. 
a. Social rehabilitation is the process of refunctionalitatie and development to enable one to be able to carry out its social functions fairly in the life of the community;

b. Social security is an institutionalized scheme to ensure that all people are able to fulfill their basic needs;

c. Social empowerment is all efforts directed to make citizens who have social problems have the power, so as to meet the basic needs;

d. Social protection is all efforts directed at preventing and handling risks from social shocks and vulnerabilities.

One of the scopes of social welfare activities mentioned above that is relevant and important to be considered in order to overcome vagrants and beggars is social rehabilitation, especially for vagrants and beggars who are caught by raids by officials/agencies so that social rehabilitation efforts are expected to be able to recover and develop the ability of vagrants and beggars who suffer from social dysfunction in order to perform their social functions fairly. Furthermore, in the provisions of Article 7 paragraph (2) of the Law of the Republic of Indonesia No. 11 of 2009 also affirmed that social rehabilitation can be carried out in a persuasive, motivating, coercive, both in the family, society and social institutions. Such social rehabilitation activities are provided in the form of:
a. Psychosocial motivation and diagnosis;
b. Care and nurturing;
c. Vocational training and entrepreneurship coaching;
d. Spiritual guidance;
e. Physical guidance;
f. Social guidance and psychosocial counseling;
g. Accessibility services;
h. Social assistance and assistance;
i. Guidance of resocialization;
j. Advanced guidance; and or
k. Reference.

2. Government Regulation of the Republic of Indonesia No. 39 of 2012 on the Implementation of Social Welfare

Government Regulation of the Republic of Indonesia No. 39 of 2012 on the Implementation of Social Welfare is an implementing regulation of the Law of the Republic of Indonesia no. 11 of 2009 which in the provisions of Article 6 letter (e) and (f) of RI Government Regulation no. 39 of 2012 is affirmed that against vagrants and beggars deserve social rehabilitation in the framework of social welfare activities for the people of Indonesia. Social rehabilitation is aimed at restoring physical, mental, and social functioning, and providing and improving skills for vagrants and beggars.

The provision of Article 5 of Government Regulation of the Republic of Indonesia no. 39 of 2012 is also affirmed that social rehabilitation can be carried out in a persuasive, motivating, coercive, both in the family, society and social institutions. Social rehabilitation done persuasively is in the form of invitations, suggestions, and persuasion with the intention to convince someone to be rehabilitated socially. 
Motivational social rehabilitation is a form of encouragement, encouragement, praise, and/or appreciation so that one is consciously moved to social rehabilitation. Coercive social rehabilitation is a form of coercion against a person in the process of social rehabilitation. Next, in the provisions of Article 7 of the Government Regulation of the Republic of Indonesia No. 39 of 2012 explained that social rehabilitation activities can be given in the form of motivation and psychosocial diagnosis; care and nurturing; vocational training and entrepreneurship coaching; spiritual mental guidance; physical guidance; social counseling and psychosocial counseling; accessibility services; social assistance and assistance; guidance of resocialization; further guidance; and or referrals.

Based on Government Regulation of the Republic of Indonesia No. 39 of 2012 mentioned above, social rehabilitation activities aimed at vagrants and beggars can be pursued through advocacy and invitation efforts until they are forced to be vagrants and beggars willing to carry out social rehabilitation. Through social rehabilitation activities, it is expected that vagrants and beggars can immediately carry out their social functions fairly and not repeat the vagrancy and begging activities:

3. Government Regulation of the Republic of Indonesia no. 31 of 1980 on the Prevention of Vagrants and Beggars

Article 58 of the Law of the Republic of Indonesia No. 11 of 2009 on Social Welfare affirms that the implementing regulation of Law Number 6 Year 1974 concerning Basic Provisions of Social Welfare (State Gazette of the Republic of Indonesia Year 1974 Number 53, Supplement to State Gazette of the Republic of Indonesia Number 3039) which existed at the time of the enactment of Law No . 11 Year 2009 is still valid as long as it is not contradictory or replaced based on the Law of the Republic of Indonesia no. 11 Year 2009 this. Subject to the provisions of this article, the Government Regulation of the Republic of Indonesia no. 31 of 1980 on the Prevention of Vagrants and Beggars remain valid and can be used as a basis or guidance in the handling or handling of vagrants and beggars because it has not been replaced and does not conflict with the Law of the Republic of Indonesia No. 11 of 2009 mentioned above.

Prevention and crime prevention efforts or criminal offenses include the field of criminal policy (criminal policy). Marc Ancel essentially asserts that the criminal policy (criminal policy) is as a rational effort of the community to tackle crime. This criminal policy is inseparable from the broader policy of social policy which consists of efforts for social welfare policy.

The relevant theories used in analyzing the problems of vagrants and beggars are the Theory of Working of the Law, Countermeasures vagrants and beggars, which are related in it to the process of working the criminal law itself in the life of society. The work of law in society involves several interrelated elements or aspects. Some aspects are: Law-Making Institutions, Sanction Activity Institutions, Role Occupants and Societal Personal Force, Legal Culture and Feed Back from the process the working of the ongoing law.

Robert B. Seidman tries to apply his views on the workings of the various factors in his analysis of the workings of enactments of law in society. Robert B. Seidman's model can be illustrated by the following chart: 


\section{Chart 1. \\ Working / Law Enforcement}

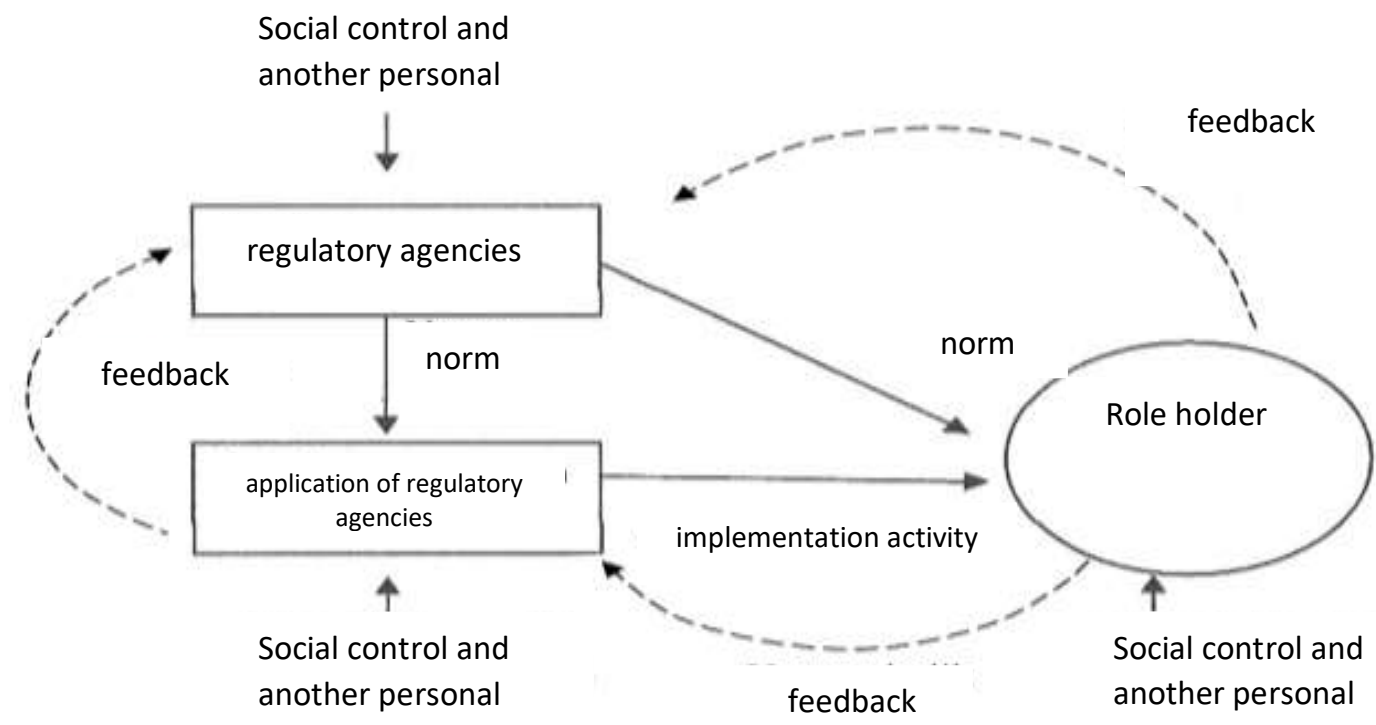

By Robert B. Seidman the above diagram is described in the following arguments:

1. Every legal rule tells about how a role occupant is expected to act;

2. How a holder of that role shall act as a response to the rule of law is a function of the rules directed against him, his sanctions, the activities of the implementing agencies and the whole complex of social, political and other forces concerning himself;

3. How the implementing agencies will act in response to the rule of law is a function of the rules of law directed against them, its sanctions, the whole complex of social, political and other forces that concern themselves and the baits the return coming from the role-holders;

4. How the lawmakers will act is a function of the rules governing their behavior, sanctions, the whole complex of social, political, ideological and other forces that are about themselves and the feedback came from role-holders and bureaucracy.

From the description of the theory put forward by Robert B. Siedman mentioned above, when associated with the problem of criminal law enforcement in the effort of countermeasures vagrants and beggars, then the implementation would be influenced also by some elements or aspects that affect the work of the above law so that criminal law enforcement in the community can run well to overcome these problems.

This research is expected to contribute to the theoretical and development of the basic concepts and theories of Criminal Law, particularly regarding the criminology perspective relating to the problems of vagrants and beggars. The criminology study here is to find out what factors are causing why someone does vagrants and beggars. And after that sought what efforts are used to overcome so that the problems of vagrants and beggars are not rampant in the city of Denpasar. Also, this research is expected to contribute or useful for the purposes of practice or law enforcement 
conducted by the Government of Denpasar together with the apparatus related law enforcers such as Police and Judges to overcome the problem of vagrants and beggars in Denpasar City.

\section{Quantitative data Vagrants and Beggars are fostered and repatriated.}

Denpasar city government in the period of three years from 2015 to 2017 especially those handled by Kasi Rehabilitation of Social Shoots, Social Affairs and Manpower of Denpasar City, has conducted coaching and repatriation of the vagrants and beggars affected by a raid by police in the city of Denpasar.

Below is presented data on vagrants and beggars who have been fostered and repatriated during the period 2015 - 2017.

Table 1. Vagrants and Beggars data are fostered and repatriated according to the qualifications Age 2015-2017 in Denpasar City

\begin{tabular}{clccccc}
\hline NO & AGE & $\mathbf{2 0 1 5}$ & $\mathbf{2 0 1 6}$ & $\mathbf{2 0 1 7}$ & AMOUNT & $\%$ \\
\hline 1 & $<-16$ years & 34 & 38 & 1 & 73 & 20 \\
\hline 2 & $17-26$ & 4 & 3 & 2 & 9 & 2 \\
\hline 3 & $27-36$ & 11 & 5 & 6 & 22 & 6 \\
\hline 4 & $37-46$ & 24 & 16 & 9 & 49 & 13 \\
\hline 5 & $47-56$ & 19 & 30 & 41 & 90 & 25 \\
\hline 6 & $57->$ & 25 & 47 & 50 & 122 & 34 \\
\hline & AMOUNT & 117 & 139 & 109 & 365 & 100 \\
\hline
\end{tabular}

Source: Social worker of Denpasar City, data processed by author.

The data of vagrants and beggars in the city of Denpasar are based on an age qualification that researchers divide into a ten-year range, where the lowest age is used 16 years because of adulthood in accordance with either competent legislation or entitled in a legal sense. Age 16 years as the limit of the lowest age there is 1.5 years. this beggar and vagrants who have been nurtured are invited by his parents. while dividing the other age range of researchers into 10 years according to Table 1 above.

For three years from 2015 - 2017 there have been 365 diria as high as to increase or decrease according to table 1 above, vagrants and beggars affected by a raid by police and subsequently fostered and repatriated. at the age of 57 years and above (34\%) are the most vagrants and beggars, probably because they are old and have no permanent jobs and the possibility of families also have no money, maybe they don't want to be placed in a nursing home, followed by the age group of $47-56$ years (25\%), although it is still somewhat younger than that age group. This age limit is actually still productive and can look for other work apart from vagrants and beggars. This age group under 16 years of 73 people $(20 \%)$ consists of children and even babies also netted raid by police, this is because her parents nagging and begging will certainly take her children, although still a baby to draw "compassion" or pity on the so get street sympathy. and it is unfortunate that young men and women still have a strong and productive force but prefer to be vagrants and beggars. 
Both vagrants and beggar men and women are dominated by those aged 47 years and over until the 80s (see Table 1 above), even girls under 16 years of age participate in vagrantsness and begging for following their parents.

Table 2. Vagrants and Beggars data are fostered and repatriated according to the Religious qualification of 2015-2017 in Denpasar City

\begin{tabular}{clccccc}
\hline NO & RELIGION & $\mathbf{2 0 1 5}$ & $\mathbf{2 0 1 6}$ & $\mathbf{2 0 1 7}$ & AMOUNT & \% \\
\hline 1 & Hindu & 73 & 45 & 94 & 212 & 58 \\
\hline 2 & Islam & 44 & 94 & 15 & 153 & 42 \\
\hline 3 & Christian & - & - & - & - & - \\
\hline 4 & Buddha & - & - & - & - & - \\
\hline 5 & Khong Hu Tzu & - & - & - & - & 100 \\
\hline & AMOUNT & 117 & 139 & 109 & 365 &
\end{tabular}

Source: Social worker of Denpasar City, data processed by author.

Over the three years from 2015 to 2017, table 2 above classifies into vagrants and beggars who are Hindu, Muslim, Christian, Buddhist and Kong Hu Tzu. but in raids about vagrants and beggars have been hit by raids and subsequently fostered and discharged from 365 people, most of them Hindus 212 people $(58 \%)$ and others are Muslims as many as 153 people (42\%). not so significant differences are affected by a raid by police, but Hindu Balinese people still do more deeds of vagrants and beggars, whereas other religious classifications do not exist.

Tabel 3. Vagrants and Beggars data are fostered and repatriated according to Raid by police Place qualification 2015-2017 in Denpasar City

\begin{tabular}{clccccc}
\hline NO & PLACE OF RAIDS & $\mathbf{2 0 1 5}$ & $\mathbf{2 0 1 6}$ & $\mathbf{2 0 1 7}$ & AMOUNT & \% \\
\hline 1 & Gunung Agung Street & 1 & - & - & 1 & 0,2 \\
\hline 2 & Imam Bonjol Street & 12 & - & - & 12 & 3,2 \\
\hline 3 & hayam Wuruk Street & 2 & - & - & 2 & 0,5 \\
\hline 4 & Waturenggong Street & 3 & - & - & 3 & 0,8 \\
\hline 5 & Tukad Balian Street & 2 & - & - & 2 & 0,5 \\
\hline 6 & Sesetan Street & 1 & - & - & 1 & 0,2 \\
\hline 7 & Serma Mendra Street & 1 & - & - & 1 & 0,2 \\
\hline 8 & Pemogan Street & 1 & - & - & 1 & 0,2 \\
\hline 9 & Marlboro Barat Street & 1 & - & - & 1 & 0,2 \\
\hline 10 & Batanta Street & 1 & - & - & 1 & 0,2 \\
\hline 11 & Gajahmada Street & 2 & - & - & 2 & 0,5 \\
\hline 12 & Around Denpasar & 90 & 139 & 109 & 338 & 93,3 \\
\hline & AMOUNT & 117 & 139 & 109 & 365 & 100
\end{tabular}

Source: Social worker of Denpasar City, data processed by author. 
Denpasar city government in addition to a program to conduct raids against vagrants and beggars who have done, also hoped that the city of Denpasar as the capital of the province can suppress the number of vagrants and beggars. But in certain seasons there will certainly be some vagrants and beggars who, after the raid, show where the vagrants and beggars were hit by raids. of the total number of 365 people during the three years, the most affected by a raid by police is in around Denpasar, meaning other than those contained in Table 3 above, this means that vagrants and beggars are still in remote parts of Denpasar.

Table 4. Vagrants and Beggars data are fostered and repatriated as qualified Origin 2015-2017 in Denpasar City

\begin{tabular}{|c|c|c|c|c|c|c|}
\hline NO & COMING FROM & 2015 & 2016 & 2017 & TOTAL & $\%$ \\
\hline 1 & Bondowoso & 18 & 50 & 42 & 110 & 30 \\
\hline 2 & Jember & 1 & 12 & 12 & 25 & 7 \\
\hline 3 & Situbondo & 2 & 16 & 9 & 27 & 7,5 \\
\hline 4 & Banyuwangi & 18 & 11 & 17 & 46 & 12,7 \\
\hline 5 & Lumajang & 1 & - & 7 & 8 & 2,2 \\
\hline 6 & Surabaya & 1 & - & - & 1 & 0,2 \\
\hline 7 & Jakarta & - & 1 & - & 1 & 0,2 \\
\hline 8 & Lamongan & - & 1 & - & 1 & 0,2 \\
\hline 9 & Madiun & - & - & 2 & 2 & 0,5 \\
\hline 10 & Sumenep & - & - & 3 & 3 & 0,8 \\
\hline 11 & Gianyar & - & - & 1 & 1 & 0,2 \\
\hline 12 & Jembrana & - & 2 & 4 & 6 & 1,7 \\
\hline 13 & Denpasar & - & - & 1 & 1 & 0,2 \\
\hline 14 & Karangasem (MG/P) & 76 & 44 & 11 & 131 & 36,2 \\
\hline 15 & Bogor & - & 1 & - & 1 & 0,2 \\
\hline 16 & Lampung & - & 1 & - & 1 & 0,2 \\
\hline & AMOUNT & 117 & 139 & 109 & 365 & 100 \\
\hline
\end{tabular}

Source: Social worker of Denpasar City, data processed by author.

According to the data processed, the origin of vagrants and beggars who successfully stamped for the last three years from 2015 - 2017 shows the data as in Table 4 above. The origin of the vagrants and beggars is mostly derived from Karangasem, namely Munti Gunung and Pedahan area of 131 peoples $(36.2 \%)$, followed by the origin of Bondowoso as many as 110 peoples (30\%), then from the origin of Banyuwangi area as many as 46 peoples or $12.7 \%$, origin from Situbondo 25 peoples $(7.5 \%)$, origin from Jember 25 peoples or $7 \%$. While from the area Lumajang, Madiun, Surabaya, Sumenep, even from Jembrana is under the number 10 peoples. 
Table 5. Vagrants and Beggars data are fostered and repatriated by Provincial Territory, 2015-2017 in Denpasar

\begin{tabular}{clccccc}
\hline NO & COMING FROM & $\mathbf{2 0 1 5}$ & $\mathbf{2 0 1 6}$ & $\mathbf{2 0 1 7}$ & TOTAL & $\mathbf{\%}$ \\
\hline 1 & Jawa Timur & 41 & 90 & 92 & 223 & 61,10 \\
\hline 2 & Bali & 76 & 46 & 17 & 139 & 38,08 \\
\hline 3 & Luar Bali dan Jatim & - & 3 & - & 3 & 0,82 \\
\hline & AMOUNT & 117 & 139 & 109 & 365 & 100
\end{tabular}

Source: Social worker of Denpasar City, data processed by author.

The researchers combine the data in Table 4 above on the origin of vagrants and beggars into the provinces according to the results of a raid by police. in Table 5 above shows that the origin of the region that originated from the province of East Java was ranked the highest of 223 people or $61.10 \%$, followed by the province of Bali as many as 139 people or $38.08 \%$, and outside Bali and East Java only three people or $0.82 \%$.

Chart 3

Provincial Areas of Origin Vagrants And Beggars.

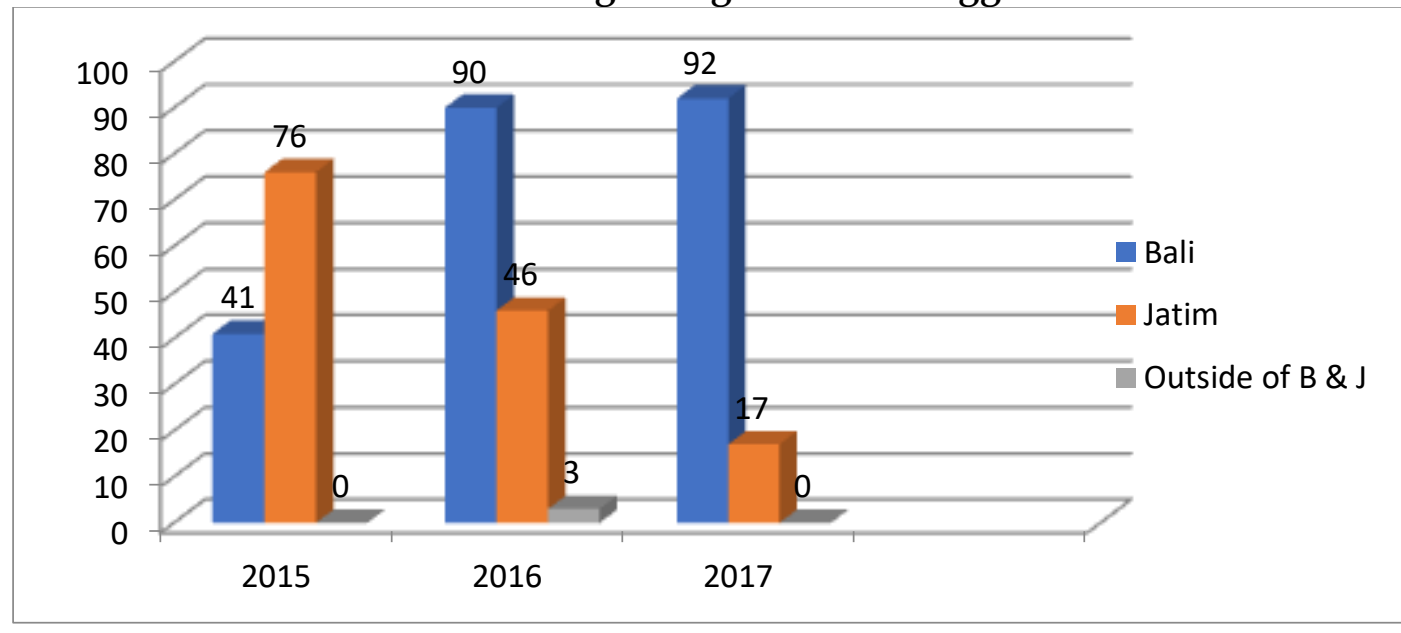

Table 6. Vagrants and Beggars data are fostered and repatriated according to Gender qualification 2015-2017 in Denpasar City

\begin{tabular}{ccccccc}
\hline NO & GENDER & $\mathbf{2 0 1 5}$ & $\mathbf{2 0 1 6}$ & $\mathbf{2 0 1 7}$ & AMOUNT & $\%$ \\
\hline 1 & Male & 26 & 54 & 36 & 116 & 32 \\
\hline 2 & Female & 91 & 85 & 73 & 249 & 68 \\
\hline & AMOUNT & 117 & 139 & 109 & 365 & 100 \\
\hline
\end{tabular}

Source: Social worker of Denpasar City, data processed by author.

After the data about age, religion, place of rasia, and the origin of vagrants and beggars, are now exposed on the sex of vagrants and beggars who were raid by police and subsequently fostered and repatriated consisting of vagrants and beggars with fewer male gender than women are men as many as 116 people and women as many as 249 people with a total of 365 people during the period since 2015-2017. Why more women? Researchers assume that women are weak so that they have more compassion 
than men. Also worthy of carrying a baby is his mother (?), So compassion, pity, will be more quickly disappear in women.

Both men and women are dominated by vagrants and beggars aged 47 and older up to the age of 80 s (note Table 1 above), even girls under 16 participate in vagrants and beggars following their parents.

Below is a grouping of genders based on Table 6 above in chart form.

Chart 4

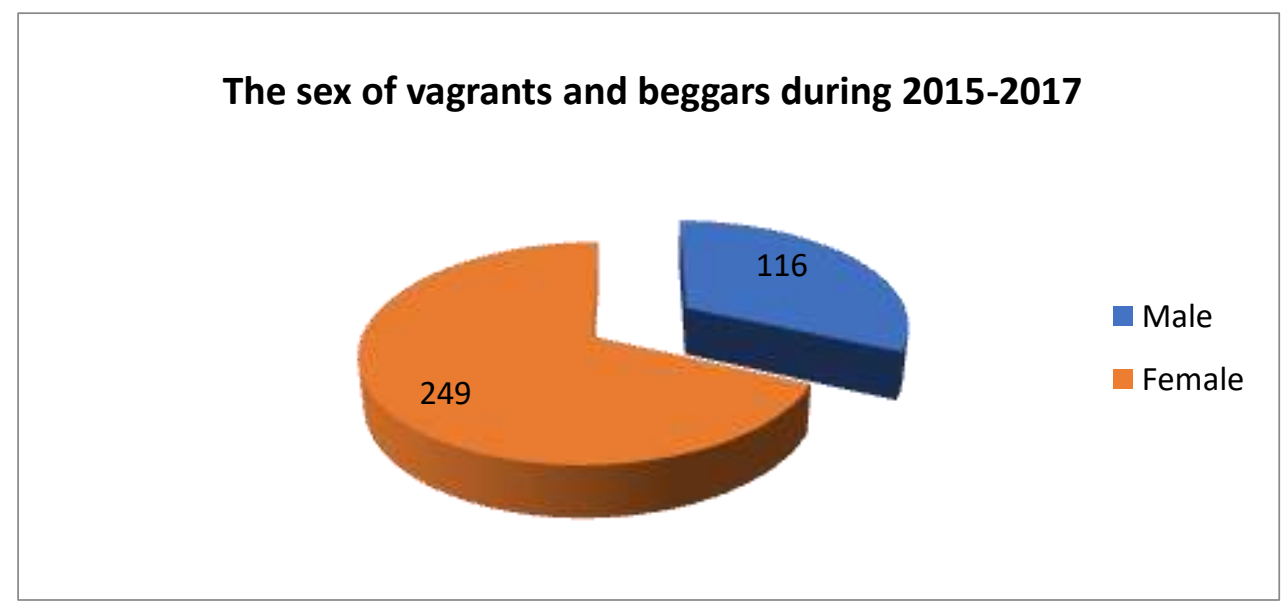

\section{Causes of Vagrants and Beggars}

Based on the results of the survey and direct observation at the study site, in four cities of Denpasar, as well as observation at the location of origin, namely Munti Gunung, Pedahan, Karangasem where most beggars come from the village, and surrounding areas, obtained several factors causing Vagrants and Beggar (Vagrants). Some of these causal factors include the factors that exist in the internal individuals and families of Vagrants, internal communities, and external societies, in cities destinations of vagrants activity.

According to Walter C Reckless with Containment theory: (1) Layer of Social Pressures consisting of (a). External Pressure, which encourages someone to commit a crime. Variables that influence a person to commit a crime include poor living conditions, conflicting economic conditions, limited group members, minority group members and lack of reasonable opportunities. (b). External pulls, pulling an individual away from social norms and given from outside bad friends, distorted subcultures and media influence. (c). Internal Pressures, encourage someone to commit a crime, they are meant to have a tense person, a feeling of inferiority or incompetence, social conflict, organic damage, and so on. (2). Containment: consists of (a) Inner Containment, referring to the internalization of the values of $p$ [conventional behavior and the development of personality traits that enable a person to resist these pressures). (b). Outer Containment, represented by an effective family and close support system in assisting law enforcement conventionality and isolating individuals from attacks from outside pressure 
From this theoretical study, it can be concluded that this theory is appropriate to be used to analyze the causes of vagrants and beggars, which are described in the study below.

These causal factors can occur partially and also together or interplay between one factor with another.

\section{Internal factors}

Internal factors and the family is meant to be a state of affairs in vagrants individuals and families that encourage them to engage in wandering and begging activities. These factors are briefly described below:

\section{A. Individual and Family Poor Living}

The poverty of individuals and families is one of the factors that determine the occurrence of wandering and begging activities originating from Munti Gunung and Pedahan Karangasem. This condition is reflected from the information obtained that the average land occupancy of vagrants and their family is relatively narrow, ie 38,23 are, with an interval between 20-60 acre. Limited land tenure is aggravated by barren land conditions, critical and lack of water availability, except during the rainy season so they can not cultivate their land year-round. Therefore, during the dry season Gepeng and his family earn income to the city of Denpasar, and several other cities in Bali, just to meet the most basic needs, namely food needs.

Difficulties in earning income from agricultural land encourage them to leave their village and forced to earn income in ways that easily and without the need for skills, that is to be vagrants.

\section{B. Age}

It turns out that the age factor gives a significant effect, whereas the third order of Table 1 (about 20\%) of vagrants and beggars encountered is very young, less than 16 years old, in accordance with the provisions of the Child Limit Act referred to as underage. Based on interviews with them (vagrants and beggars) it is known that this young age factor provides an opportunity for them to engage in wandering and begging activities because of the absence of thinking of too much shame. Even they (the kids) look cheerfully running around and joking with their fellow vagrants' friends. This condition is very different or inversely proportional to those who have reached the age of 57 years and over until the age of 80 which is the first sequence of Table 1 above.

Women over the age of 40 seem to provide a greater opportunity to gain "compassion" from city dwellers. The condition is very reasonable if studied further where they will get some benefits, among them are as follows: (i) prospective money giver will pity to see a mother with a small child who carried her; (ii) the money earned will be more, in addition to sometimes they are also given food, especially for the child they carry.

\section{Formal education}

Not explained in the data in the social worker of Denpasar city about educational factors also influence the respondents to perform activities vagrants. At the age level that is still categorized children, they should be following formal education activities at 
school. However, they choose to be vagrants compared to school because they do not have the financial ability to school needs as a result of the poverty of parents. But obviously, the children who participated in vagrancy and begging means they are not attending school.

D. Permission of Parents

Children who perform vagrancy activities and begging them have got "permission" from their parents and even "told" by their parents. The reasons mentioned above are also justified given the socio-economic conditions of children's parents who become vagrants in the hamlet are very poor. So in the dry season, they are "forced" to let their children and "send" their children to seek income to help meet their household needs.

\section{E. Mental Attitude}

This lazy state of mental attitude is also encouraged by the lack of control of other citizens or the impression of the permissiveness of the vagrants and begging activities undertaken by citizens due to their very limited economic circumstances. Such a situation also contributes to and preserves the begging culture.

\section{External Factors / Environment}

In this study, the environmental factors that are meant are some factors that are around or around the respondents either in the area of origin or in the destination area. These factors include:

\section{A. Condition of water requirement}

Questioning the condition of the water needs in Munti Gunung and Pedahan Hamlet, and also the adjacent hamlets can not seem to be released from the same conditions in the villages located in Kubu Sub-district, Karangasem where the water factor is the main factor as the limiting factor in the activity of citizens.

Naturally, Dusun Munti Gunung and Pedahan, including areas that are very arid and barren as a result of limited availability of water. In this dry season, the poor are very difficult to obtain water that is used for drinking water and other household needs. This condition is then encouraged for poor citizens with "forced" to get out of the hamlet to earn income because in the dry season they can not perform economic activities.

\section{B. Plant Condition for Agriculture}

Dusun Munti Gunung and Pedahan, Kubu Karangasem, have conditions that are less supportive when associated with farm management or agricultural development (including livestock) on dry land.

They generally grow crops (beans and tubers) that do not require much irrigation water. The use of seeds, fertilization including the handling of pests and diseases can be said to be very low quality so that the resulting productivity is also low. These conditions further resulted in them earning a low income, while the need for family life of vagrants including other residents higher. Therefore, the limited resources and the amount of income encourage them to get out of the hamlet to earn an income in the city.

C. Limited Access to Information and Business Capital 
Limitations in accessing this information are also exacerbated by limited media ownership of media infrastructure, such as television, newspapers and so on. Apparently, this limitation is caused by the lack of widespread electricity network in Munti Gunung and Pedahan Hamlet, Kubu Sub-district, Karangasem.

Other access that is difficult to obtain is business capital. This difficulty caused by the acquisition of venture capital requires some conditions that are very difficult to be met by the villagers, including the vagrants family. The main requirement required is the existence of collateral in the form of land certificate.

D. Disadvantages of Flat Handling in Town

Although the government in Denpasar City, has made maximum efforts in dealing with vagrants in their respective areas, the results have not been maximized. This condition is seen from the vagrant that has been arrested and returned to the village will always return to perform activities. In fact, in addition to being arrested, vagrants are also fostered, but it turns out after they were discharged back home. Therefore, it appears that the handling of the flakes has not been effective. In addition, although the government as in the city of Denpasar has installed banners containing so that citizens do not give alms to vagrants, but still there is a gift to the vagrants.

\section{Vagrants and Beggar Countermeasures}

According to Government Regulation of the Republic of Indonesia No. 31 Year 1980, vagrants and beggars are not in accordance with the norms of life of the Indonesian nation based on Pancasila and the 1945 Constitution, therefore it is necessary to carry out mitigation prevention, namely Preventive, and Repressive as stated by Edward $\mathrm{H}$. Sutherland and Cressey as well as the study of countermeasures by Graham with the primary, secondary, and tertiary prevention models.

a. Preventive action is an organized effort intended to prevent the occurrence of vagrants and beggars within the community, aimed at both individuals and community groups thought to be the source of the emergence of vagrants and beggars, which are based on Article 6 such efforts include: counseling and social counseling, training, education, provision of assistance, expansion of employment opportunities, local settlements, health promotion, supervision and further counseling to various parties related to pervagrants and begging, so as to prevent the occurrence

- vagrancy and begging by individuals or families especially those who are in a difficult situation of their livelihoods;

- The widespread influence and consequence of vagrants and beggars in society which can disrupt public order and welfare in general;

- vagrancy and refinement by vagrants and beggars who have been rehabilitated and have been transmigrated to new resettlement areas or have been returned to the community.

b. Repressive efforts are organized efforts intended to reduce and / or eliminate vagrants and beggars aimed at either a person or group of persons suspected of vagrants and begging. In Article 9 described the repressive efforts include: raid by police, temporary shelter to be selected, and abundance. 
In the provisions of Article 11 of the Government Regulation of the Republic of Indonesia No. 31 of 1980 described that vagrants and beggars exposed to raid by police were accommodated in temporary shelters for selection. Selection is intended to establish the qualifications of vagrants and beggars and as a basis for establishing further action consisting of:

- Released on condition;

- Included in the Social Home;

- Return to parent / guardian / family / hometown;

- Submitted to Court;

- Given health services.

c. Rehabilitation efforts are organized efforts covering shelter, selection, sponsorship, channeling and follow-up efforts, so that vagrants and beggars, again have the ability to live properly in accordance with human dignity as citizens of the Republic of Indonesia. This rehabilitative effort is implemented through Social Home.

The above-mentioned shelter is aimed at researching / selecting vagrants and beggars implanted in the Social Home. The selection is intended to determine the qualifications of social services to be provided. Furthermore, sponsorship is aimed at changing the mental attitude of vagrants and beggars from a non-productive state into a productive state. In carrying out the above sponsorship efforts vagrants and beggars are given physical, mental and social guidance, education and training and work skills according to their talents and abilities. Next are follow-up efforts aimed at not returning themselves to vagrants and beggars. The above-mentioned follow-up effort is done with:

- Increase self-awareness;

- Maintain, establish and improve socio-economic capacity;

- Growing awareness of community life.

In addition to Sutherland's views, Graham also advocated crime prevention strategies to be 3:

1. Primary prevention, applied as a crime prevention strategy through social, economic and other fields of public policy, specifically as an effort to influence criminogenic situations and the underlying causes of crime. The main objective is to create conditions that provide hope for successful socialization for every community;

2. Secondary prevention, usually found in criminal justice policies and their implementation. Secondary prevention can be in the form of general prevention and special prevention which includes early identification of criminogenic conditions and efforts that affect these conditions. The preventive role of the police is placed in secondary prevention, as well as mass media surveillance, urban planning, and building design and construction;

3. Tertiary prevention, pays great attention to preventing recidivism through the political role and agents in the criminal justice system. All acts of tertiary 
prevention revolve around informal justice sanctions and conditions of debt repayment for victims as well as improvement of offenders and prison sentences.

Crime prevention strategies must be more practical theoretical, so some experts decide to divide crime prevention into 3 approaches, namely:

a) Prevention of crime through social approaches is usually called social crime prevention, all its activities aim to eradicate the root causes of crime and opportunities for individuals to commit violations. The targets are both the general population of the population and groups that are specifically at high risk for violations;

b) Prevention of crime through a situational approach is usually called situational crime prevention, the main concern is reducing the opportunity for a person or group to commit violations; and

c) Crime prevention through community approach or community crime prevention, as a step is shown to improve the capacity of the community to reduce crime by increasing their capacity to use informant control ${ }^{16}$

\section{a. The Criminal Act (Penal Code)}

That besides countermeasures as stated in Law no. 11 Year 2009 on Social Welfare, RI Government Regulation no. 39 of 2012 on the Implementation of Social Welfare, and Government Regulation no. 31 of 1980 on the Prevention of Vagrants and Beggars mentioned above, in order to overcome or handling the problems of vagrants and beggars can also be applied to the prevention efforts through the application of criminal law (penal effort) that is in the form of criminal sanctions against vagrants and beggars.

The prohibition of begging or wagging is clearly defined in the Criminal Code. The vagrants and begging activities are qualified as a criminal act that is as avertredingen in the field of public order as stipulated in the provisions of Articles 504 and 505 of the Penal Code.

2. Local Regulation of Denpasar City no. 15 of 1993 jo. No. 3 of 2000 on Public Cleanliness and Order

Especially for Denpasar City area, the prohibition and criminal witness for the activities of vagrants and beggars are also regulated in Article 35 paragraph (4) jo. Article 37 paragraph (1) of Denpasar Regional Regulation no. 15 of 1993 jo. No. 3 of 2000 on Public Cleanliness and Public Order affirms as follows:

- Article 35 paragraph (4): "No business / begging / begging activity, singing or other similar business";

- Article 37 paragraph (1): "Any person who violates the provisions referred to in the articles of Chapter II to Chapter X shall be liable to a maximum of 3 months imprisonment or a maximum fine of Rp. 5.000.000, - (five million rupiah) ".

Starting from the description of the Legislation related to the prevention of vagrants and beggars mentioned above, it can be seen that there are 2 (two) ways / efforts that

${ }^{16}$ M Kemal Darmawan, (1994). Strategi Pencegahan Kejahatan, Bandung: Citra Abadi Bhakti, h. 17 
can be done in order to overcome the problems of vagrants and beggars is through penal way ( criminal law) and non-penal ways (not / outside of criminal law). Such non-penal measures can be seen in the provisions of Law no. 11 of 2009 on Social Welfare, Government Regulation of the Republic of Indonesia No. 39 of 2012 on the Implementation of Social Welfare, and Government Regulation of the Republic of Indonesia No. 31 of 1980 on the Prevention of Vagrants and Beggars which emphasizes the prevention of preventive, persuasive and rehabilitation efforts. Next, the penal way is repressive measures that are repressive in the form of criminal sanctions imposed against vagrants and beggars as stipulated in Article 504 of the Criminal Code, Article 505 of the Criminal Code and specifically in the area of Denpasar City is regulated in Article 35 paragraph (4) jo. Article 37 paragraph (1) of Denpasar Regional Regulation no. 15 of 1993 jo. No. 3 of 2000 on Public Cleanliness and Order.

\section{Conclusion}

Factors that cause vagrants and beggars are: (a) Internal factors: poor living individuals and families; age; formal education; parental permission; mental attitude; (b). external/environmental factors: the condition of water requirement; crop conditions for agriculture; limited access to information and venture capital

Vagrants and beggars Countermeasures are: Preventive measures are organized businesses intended to prevent the emergence of vagrants and beggars within the community, aimed at both individuals and community groups thought to be sources of vagrants and beggars, including counseling and social counseling, training, education, grant-making, employment opportunities, local settlements, health promotion, supervision and further counseling to various parties related to pervagrants and begging, so as to prevent the occurrence: Repressive efforts are organized efforts aimed at reducing and/or eliminating vagrants and beggars aimed at either individuals or groups of persons suspected of vagrants and begging including a raid by police, temporary shelter to be selected, and overflow. And Rehabilitation efforts are organized efforts covering shelter, selection, sponsorship, channeling and followup efforts, so that vagrants and beggars, again have the ability to live properly in accordance with human dignity as citizens of the Republic of Indonesia. This rehabilitative effort is implemented through Social Home. In order for the government to continuously strive for the cities in Bali free from vagrants and beggars.

\section{Acknowledgments}

Thank you for all those who have contributed to research / scientific work at the Magister Study Program (S2) Postgraduate Law Study Program at Udayana University, Head of the Social and Workers Agency of Denpasar City and also family, friends and institutions where the research has provided data and input to me in making this research / scientific work.

\section{References}

Book

Darmawan, M Kemal. (1994). Strategi Pencegahan Kejahatan. Bandung: Citra Abadi Bhakti 
Direktorat Pelayanan dan Rehabilitasi Sosial Tuna Sosial. (2005). Standar Pelayanan Minimal Pelayanan dan Rehabilitasi Sosial Gelandangan dan Pengemis. Jakarta: Depsos RI.

Irawan, D. D. (2013). Pengemis Undercover Rahasia Seputar Kehidupan Pengemis. Jakarta: Titik Media Publisher.

\section{Journal}

Ahmad, M. (2010). Strategi Kelangsungan Hidup Gelandangan-Pengemis (Gepeng). Jurnal Penelitian, 7(2), 1-16.

Arifani, M. A., Sari, A. L., \& Rifkah, R. (2018). Aplikasi Regulasi Pembinaan Anak Jalanan Oleh Dinas Sosial Dan Penanggulangan Kemiskinan Kota Bandung. JISPO: Jurnal Ilmu Sosial dan Ilmu Politik, 8(2), 147-155. https://doi.org/10.15575/jispo.v8i2.3782

Bahfiarti, T., Muhammad, R., \& Tarawe, A. (2019). Kajian Penanganan Anak Gelandangan Dan Pengemis Di Kota Makassar (Study on Handling of Children and Beggars in Makassar City). Jurnal Inovasi dan Pelayanan Publik Makassar, $1(2), 43-54$.

Dahri, I. (2016). Studi Tentang Perlindungan Dan Pembinaan Gelandangan Anak Di Kota Makassar. Jurnal Tomalebbi, (2), 1-12.

Iqbali, S. (2006). Studi Kasus Gelandangan-Pengemis (Gepeng) Di Kecamatan Kubu Kabupaten Karangasem. Piramida, 4(1).

Nusanto, B. (2017). Program Penanganan Gelandangan Dan Pengemis Di Kabupaten Jember (Handling Programs Of Vagrants And Beggar) In Jember District. Politico, 17(2). 339-360. http://dx.doi.org/10.32528/politico.v17i2.1002

Rohmaniyati, R. (2016). Pemberdayaan Gelandangan Dan Pengemis (Gepeng) Melalui Usaha Ekonomi Produktif (UEP) Di Lembaga Sosial Hafara Bantul, Daerah Istimewa Yogyakarta. Jurnal Elektronik Mahasiswa Pend. Luar Sekolah-S1, 5(2).

Zefianningsih, B. D., Wibhawa, B., \& Rachim, H. A. (2016). Penanggulangan Gelandangan Dan Pengemis Oleh Panti Sosial Bina Karya "Pangudi Luhur" Bekasi. Prosiding Penelitian dan Pengabdian kepada Masyarakat, 3(1). 1-18. https://doi.org/10.24198/jppm.v3i1.13600

\section{Newspaper}

Anonymous. (2013). Tak Mempan Dirazia, Gepeng Muncul di Kuta. Jawa Pos Radar Bali. date June 21, 2013, page 23, column 5.

Anonymous. (2012). Siaga Gepeng Sebar Himbauan. http://koranbalitribune.com/2012/04/15/siaga-gepeng-sebar-imbauan/. accessed September 3, 2013.

\section{Internet}

Direktorat Jenderal Rehabilitasi Sosial Kementerian Sosial RI. (2010), Fenomena Munculnya Gelandangan dan Pengemis. http://rehsos.kemsos.go.id/modules.php/article=1066. accessed Desember 3, 2013.

\section{Legislation}

The Criminal Code (KUHP).

Republic of Indonesia Law No. 11 of 2009 concerning Social Welfare. 
Republic of Indonesia Government Regulation No. 39 of 2012 concerning Implementation of Social Welfare.

Republic of Indonesia Government Regulation No. 31 of 1980 concerning the Management of Bums and Beggars.

Regional Regulation of Denpasar City No. 15 of 1993 jo. No. 3 of 2000 concerning Cleanliness and Public Order. 